\title{
Effects of Water Stress on Vegetative and Reproductive Traits of Three Commercial Cotton Varieties in Field Conditions in Central Iran
}

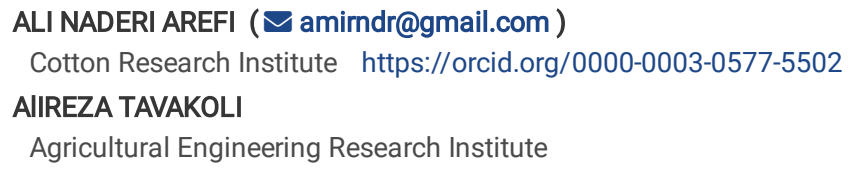




\section{Abstract}

Background

water scarcity is one of the most important factors that restricts crop production specially, cotton which must planted in areas without cold temperature limitation. Most of such area in Iran encounters drought events, hot temperatures and high atmospheric evaporative demand. So, understanding of stress severity and cultivar responses will help to better management of crop in stress conditions. Our previous study showed that cultivar responses in view of some physiological and morphological aspects were highly different in water stress condition. In this study we focused on yield formatting traits.

Results

Three cotton commercial varieties; Khorshid, Khordad and Varamin studied in sever, mild and without water stress. In normal condition zero type cultivar, the khorshid, produced the highest seed cotton yield. Varamin cultivar had more and longer sympodial branches which could raise it's yield. Also, Varamin cultivar's seed cotton yield was higher than the others ( $3617 \mathrm{~kg}^{-1}$ ha compared with 2477 and 3060 for khordad and khorshid, respectively). Khorshid was superior to the others at sever water stress.

Conclusion

Seed cotton yield showed high correlation whit boll number and boll weight and vegetative aspects such as plant height, node number and sympodial branches number. Management for developing more sympodial branches results in higher bud and flower and will increase the yield. Totally, we recommend Khorshid and Varamin cultivars for normal condition and Khorshid for sever stress conditions.

\section{Background}

Cotton is a crop of tropical and subtropical regions but the seed cotton yield is highly influenced by abiotic stresses like drought (Iqbal et al., 2017). Drought and scarcity of irrigation water in summer leads to substantial reductions in cotton yield. Over the last 50 years, drought stress alone was responsible for approximately $67 \%$ of the cotton lint yield losses in USA, one of the top cotton producing countries in the world (Khan et al., 2018). Iran has a predominantly arid and semi-arid climate where the drought hazards and their variability are the crucial concerns for water resources management (Sharafati et al., 2020). Water-deficit stress impaired various morphological traits like reduction in cell and leaf expansion, stem elongation, root shoot ratio, number of nodes and leaf area index of cotton (Saleem et al., 2016). Under water stress, the boll weight of cotton remains relatively stable, while both the leaf area and leaf photosynthetic rate decrease greatly (Liang et al., 2021). Because of different potential of vegetative growth, leaf number and size of cotton genotypes, their transpiration and water use is variable which causes to different response to soil water content. Consequently, seed cotton yield of genotypes are highly differ in responses to water treatments (Bozorov et al., 2018; Karademir et al., 2011; Naderi arefi et al., 2017). Sezener et al., (2015) screened cotton cultivars for drought tolerance under filed conditions and observed that the genotypes with the least change in seed cotton yield under drought stress were Zeta 2, Delcerro, Nazilli 87 , and DAK 66/3 which were also the most water-use efficient cultivars. The root, leaf, bud, and flower can be grown repeatedly with re-watering to compensate for injuries under drought stress. Studies have shown that the cotton yield of certain cotton cultivars were improved when the irrigation volume was moderately decreased (Dağdelen et al., 2009; Papastylianou and Argyrokastritis, 2014).

Cotton responses to water deficit stress included of changes in plant height, number of monopodial and sympodial branches per plant, number of boll per plant, seed index, yield and fiber characteristics (Etrat and Abdul, 2020) Wu et al., (2018) reported that decrease in the number of opening bolls might be the major reason for the observed decrease in lint and cottonseed yields. Bozorov et al., (2018) reported that water deficit significantly influenced plant height, the number of internodes, and sympodial branches. However, yield components such as the number of bolls, boll seed, lint mass, and individual plant yield were significantly reduced only in one of studied genotypes (Chandrasekar and Sai, 2015).

DeLaune et al., (2020) concluded that controlled water stress until critical growth stages and using cover crops should be considered as best management approaches to conserve water resources while sustaining cotton production in the Southern Great Plains. By determining the optimum soil water levels that not induces water stress responses, thrifty use of irrigation water will be accessible. It is reported that cotton crop irrigated 6 times during whole of its growing period at 21 days interval produced significantly highest seed cotton yield ( $\left.2271.16 \mathrm{~kg} \mathrm{ha}^{-1}\right)$ in comparison to five times during the whole of its growing period at 28 days interval, and four times at 35 days interval (Iqbal et al., 2021). Net photosynthesis, cotton yield and fiber quality all approached to the highest values in the optimal treatments (the optimal groundwater depths of $1.4 \mathrm{~m}$ and of $1.8 \mathrm{~m}$ ) and reduced boll number played a critical role to decrease seed cotton yield (Zhang et al., 2017).

Among the yield components boll density (bolls ha ${ }^{-1}$ ) was the dominant driver of drought-induced yield loss, but reduced boll mass and seed number per boll also contributed somewhat to yield loss (Hu et al., 2018). Accessibility of water in root zone, by retinol management of soil water will result in reducing of yield loss. Zhang et al., (2017) reported that increased water consumption in the deep soil layers resulted in increased shoot dry weight, seed cotton yield and WUE. In this study we consider the effects of soil water levels on cotton yield and yield component to achieve better information of water management in research conditions.

\section{Results}

Water stress affected plant height, node number, height to node ratio, monopodial and sympodial branches number and length, significantly (table 2). Cultivars were significantly different in view of studied traits. Interaction of cultivar and stress levels on node number and height to node ratio was not 
significant, but response of cultivars to water stress in view of plant height, monopodial and sympodial branches number and length, were significantly different and this differences affected by conditions of the year of experiment (table 2).

\section{Vegetative traits}

The highest number of node observed in Khorshid cultivar. The heihighest ratio of height to node, monopodial branches and length of monopodial branches belong to varamin and Khordad cultivars. Varamin Also, had the highest number of sympodial branches. In conditions of unlimited water availability (S0) Khorshid had the most number of boll and seed cotton yield (table 8), but as soil water content reduced to ( $45 \%$ of Fc. or mild stress), the Varamin cv. Performed better than the others in view of boll number and seed cotton yield (table 2).

Water stress affected monopodial branch number, significantly, but length of this type of branches did not show significant response to water stress levels (table 1). In low level of water availability, the number of monopodial were low but relatively long, which appeared in insignificant differences between stress levels (table 3). Varamin had more (5.5) and longer $(39.3 \mathrm{~cm}$ ) monopodial branches than Khorshid and Khordad (table 10). In the other study in research conditions, Varamin monopodial branch number and length reported as 4 and $30 \mathrm{~cm}$, respectively (Naderi Arefi et al., 2015). Khorshid had the lowest and shortest sympodial branches than two other cultivars (table 2).

Water stress levels influenced on number and length of sympodial branches, significantly $(\mathrm{p}<0.01)$. The cultivars differences were significant, too (table 1$)$. In $85 \%$ Fc, Khordad had the longest (27.5) and most number of sympodial branches and was superior to the others. Increasing of water stress led to similar response of two cultivars in view of length $(24.5 \mathrm{~cm})$. The lowest number of sympodia branches observed in Khordad at $25 \%$ Fc, and the lowest length of sympodial belong to Khorshid at $25 \% \mathrm{Fc}(3.6 \mathrm{~cm}$, table 3$)$. Similar differences in reduction of sympodial of different genotypes by water stress reported by sahito et al., (2015) and ehsan et al., (2008).

\section{Yleld and yield components}

The highest mean of boll number ( 28.2 bolls) produced by Khorshid in appropriate condition (water availability of $85 \%$ Fc). Lowering water content to $45 \%$ Fc reduced boll number of this cultivar. Varamin performed better in this level of water stress with 18.2 boll per plant (table 2). More reduction of water availability to $25 \%$ Fc led to insignificant difference between cultivars, while Khorshid was relatively better, but laid in same statistical group (table 2 ).

Khorshid as a zero type cultivar, possess very short sympodial branches and lower leaf area which probably led to thrifty use of water and retention of bolls on this points and so, performed better than the others in severe stress $(25 \% \mathrm{Fc}$, table 2$)$. In varamin and khorshid varieties with higher potential of vegetative development and size, water stress reduced the number and length of sympodial branches which reflected in reduced boll number.

In high level of water availability, cultivars did not show significant differences in boll weight and Varamin was superior to others with boll weight of $4.8 \mathrm{gr}$ (table 2).

In condition of water availability ( $85 \%$ Fc) seed cotton yield of Khorshid and Varaimin cultivars was higher than Khordad, but in mild stress (45\% Fc) potential of Varamin in retention of more and heavier bolls, increased the yield of this cultivar to $3617 \mathrm{~kg}$ ha $^{-1}$, while the yield of Khorshid and Khordad were 3060 and $2477 \mathrm{~kg} \cdot \mathrm{ha}^{-1}$, respectively (table 2). In severe stress (25\% Fc) Khorshid as a zero type cultivar performed better than the others.

\section{Correlations}

Correlation in the broadest sense is a measure of an association between variables. The Pearson correlation coefficient which used for better understanding of treats relations is typically used for jointly normally distributed data. This correlation coefficient scaled such that it range from -1 to +1 , where 0 indicates that there is no linear or monotonic association, and the relationship gets stronger and ultimately approaches a straight as the coefficient approaches an absolute value of 1 (Schober et al., 2018). The correlation of traits presented in table 3. Cotton yield associated to yield components and vegetative aspects of plant in different growth stages. Plant height determined by node number and internode length. Correlation of plant height with node number was positive and significant $(0.34$, table 3$)$. Height to node ratio is an indicator of internode length that correlated highly and positively with plant height $(0.74 * *)$. Plant height correlation with length of sympodial and monopodial branches was significant $(p<0.05)$ and positive, 0.28 and 0.41 , but it's correlation with number of this branches was not significant, imply that plant height affected by internodes growth higher than node number. Number of symposia showed positive correlation with the number of monopodia ( $0.56^{* *}$, table 3). Monopodial branches develops early of season on nodes 5 to 7 and sufficient growth of them produces enough assimilate for development of more and robust sympodial branches (Stewart, 2010). Sahito et al., (2015) reported similar results.

Correlation of seed cotton yield with boll number was high and positive $\left(0.95^{\star \star}\right.$, table 3$)$. Seed cotton yield correlation with boll weight was positive but lower than that of boll number $\left(0.64^{* *}\right.$, table 3$)$. Correlation of boll number and boll weight was positive $\left(0.42^{\star}\right)$. Seed cotton correlation with plant height and node number was positive and significant $(0.73$ and 0.57 , respectively). Correlation of yield with height to node ration and number of sympodial branches was significant, too (table 3). Sympodial branch number highly correlated with yield components imply that the higher number of this branches, increases probability of higher seed cotton yield.

\section{Discussion}

Plant height is of the most important traits that, usually affected by input and genetic structure of parental line of cultivar (Zabihi et al., 2013). Plant height of Gossypium. hirsutum and G. barbadense can be reach to more than 1.5 and 2.5 meter, respectively (Naderi Arefi et al., 2014), but in commercial variety of both species in the region plant height ranged 1-1.5 meter. 
Five first node of cotton main stem supports vegetative growth and reproductive or sympodial branches commences the growth later (Ritchie et al., 2007). Because of their effects on development of sympodial branches and reproductive organs, the number of monopodial branches is amongst the important traits of cotton plants (Sahito et al., 2015). The number of monopodial branches of Varamin cultivar highly reduced in response to water stress, but this trait changes in Khorsid was not considerable. This response is in accordance with mentioned growth habit of them.

Node number influences by cultivar potential in exploitation of resources and growth of internodes. Length of internodes mostly affected by availability of soil water (Arab Salmani and Baniani, 2015), while node number usually affected by nitrogen availability (khan et al., 2019). Because of light induced effects on growth, dense canopy of cultivar can be effective in main stem height, node number and finally, height to node ratio. Thus, because of potential for dense planting of Khorshid cultivar, its early and dense canopy could exploit inputs, especially water, efficiently and can better response in stress conditions as well as showed in this study.

Height to node ratio is a mean for monitoring cotton plant growth and development rate which must be determined for different regions (Stewart et al., 2010). In this study, combination of plant height and node number were such that the height to node ratio ranged between 3.3 to 4.4 and the highest value observed in Varamin cultivar. Kerby et al., (1998) evaluated the information of 104 field (1982-1991) and reported that the appropriate level of the ratio is 4.54. Naderi arefi and Hamidi (2013) reported similar results at the conditions of Garmsar in central Iran, too which is similar to our result in normal condition. Reduction of soil water leads to shorter internodes and reduction of height to node ratio. In Oklahoma, ratios of less than 1.5 observed in cotton planted after wheat (bowman et al., 2013). In condition of this study, the ratio was higher even at stress treatments. At the early of season, temperature is not high but, because of higher relative humidity, atmospheric demand is low and this condition helps plant to have more vegetative growth, more nodes and internode formation. This growth restricted highly in mead season because of sharp increment of temperature to more than $42{ }^{\circ} \mathrm{C}$ as demonstrated by reduction of all vaegetative traits in stress treatments (table 2).

The most important component of yield is boll number per unit area which it's high correlation with yield confirmed in various studies (Smith and Hamel, 2012; Naderi Arefi and Hamidi, 2013). Also, Mehrabadi (2014) reported high correlation between seed cotton yield, boll number, biomass and harvest index in stress condition. Low humidity is one of the most important factors affecting flower and boll production and retention of these organs on cotton (Sawan et al., 2018). Management of environmental and physiological factors for build up more boll number in unit area has high effect on yield raise (Alishah and Ahmadi Khah, 2009). Most of cotton production systems, depends on first and second fruiting point for economic yield (Hake et al., 1996). So high potential of soil and leaf water is critical for development of bolls.

At sever stress condition ( $25 \%$ of Fc) Khorshid and Varamin were superior to Khordad in view of boll number per plant. Khorshid is a zero type cultivar with limited vegetative growth and so, lower transpiration and probably, efficient use of water. Superiority of Varamin cv. Related to its higher number of reproductive organs and it's ability of producing more boll per plant.

Mild stress reduced boll weight of all cultivars, differently, but because of shedding of some flowers and squares, weight of remaining bolls did not reduced sharply (Papastylianou and Argyrokastritis, 2014) similar to sever stress. Also, retention of more bolls on first flowering points in stress conditions can increase mean boll weight (Petigrew, 2004). Cultivars responded evenly to severe stress (25\% Fc) in view of boll weight. Similar results reported by Basal et al., (2009), Fathi Sadabadi and Navabi (2012), Najib-ullah et al., (2017). One consequence of water stress is shedding of vegetative organs. It seems that severity of stress in $25 \%$ Fc caused to attenuate most of tolerance mechanisms and shedding of vegetative organs for plant survival. Confirming this result, Ul-Allah et al., (2021) highlighted the negative effects of drought stress on assimilate accumulation and portioning in reproductive tissues of cotton which finally converts into the fiber. Competition of bolls for assimilates will reduce boll weight and expected to this correlation be low or negative. Probably, lower number of bolls, especially in stress conditions leads to sufficient loading of each boll and correlated positively. Despite our results, other researches indicated negative correlation (Balkcom et al., 2010; Liu et al., 2013).

Drought promoted carbon allocation in older bolls (Zhao et al., 2019). In Khorshid cultivar flowering points (specially, first and second) are near to main stem and may directly related to main stem vascular bundle and receive water, minerals and assimilates directly, from stem and subtending leaves, so that, in condition of sever water shortage, produced $1955 \mathrm{~kg}$.ha-1 seed cotton. Chen et al., (2021) innovated a boll-leaf system (BLS) study, which includes the mainstem leaf, sympodial leaf, and non-leaf organs, as the basic unit of the cotton source-sink relationship and yield formation. Based on their research, there was a better linear correlation between the net $\mathrm{CO}_{2}$ assimilation rate, respiration rate of $\mathrm{BLSs}$ and boll biomass. This correlation can be a cue of higher boll retention ability of Khorshid which its short branches leaves shedding is lower in stress condition than more vegetative cultivars with higher leaf damage. Furthermore, Pilon et al., (2019) reported that soluble carbohydrates and starch concentration in leaves were more affected by drought than those of floral tissues, with corresponding reduction in dry matter, suggesting that flowers are more buffered from water-deficit conditions than the adjacent leaves. So, it seems that, cultivars like Khorshid which produces more reproductive organs relative to total leaf per plant, performs better in severe stress condition.

\section{Conclusions}

This study highlights the effects of water deficit stress on vegetative and reproductive aspects of cotton plant. It also highlights the differences of cotton cultivars in response to drought stress. So that, zero type cultivar of Khorshid responses was more stable than the others and produced the most seed cotton yield in severe stress condition. In normal condition, all cultivars produced high yield, but Khorshid was superior to Varamin and Khordad. Superiority of Khorshid was due to possibility of dense planting and higher number of boll per plant and so, unit area. In mild stress Varamin cultivar with more and longer sympodial branches, produced more boll and had the highest seed cotton yield. Yield highly correlated with number and weight of boll. Also, yield correlation with plant height, node number and number of sympodial branches was significant. Thus, input management must be so that the potential of plant for producing of this trait exploited highly, and the most amount of resources could be allocated to bolls. 


\section{Methods}

The experiment conducted in filed located at the Garmsar agricultural research station of Semnan province in central Iran. The experimental design was split plot in RCBD with three replications. Water stress treatments arranged in main plots and three cotton commercial genotypes including Varamin, Khorshid and Khordad planted as subplots. Planting date in 2017 season was May 10 and in 2018 was May 13. For land preparation, the field ploughed in autumn of past years. Conventional operations including disk and land leveling done before planting. Starter fertilizers including nitrogen, phosphorus and potassium broadcasted and disked then. For pre-emergence control of weeds Trifluralin 48\% EC consumed and in season control of weeds done by hand.

Each sub plot included of 5 row with 8 meter long and plant spaced on rows by 10 centimeters. Row spacing was 75 centimeter (thinned in 2 true leaf stage to 8 plant per $\mathrm{m}^{2}$ ). Seeds of three commercial cultivars (Varamin and Khordad) planted by hand in depth of 5 centimeters. Khorshid is a zero type cultivar so planted densely in $35 \mathrm{~cm}$ row space and $15 \mathrm{~cm}$ of plants on row (19 plant per $\mathrm{m}^{2}$ ). Pest and disease monitored and controlled by recommended chemicals.

Three water stress treatments included of: S1 as control (irrigation after soil humidity of root zone reaches to $85 \%$ Fc), S2 as mild stress (irrigation after depletion of root zone humidity to $45 \% \mathrm{Fc}$ ) and S3 as severe stress (irrigation after depletion of root zone humidity to $25 \%$ Fc). Evaporation of pan used for determining time of soil samplings. in each time of samplings, after about 50, 100 and $200 \mathrm{~mm}$ evaporation from pan, soil samples taken and if the water level was at treatment area, irrigation accomplished and if was not in determined levels, sampled soil mass returned back to sampling hole and the hole covered by 10 centimeter of top soil. Soil water percent determined after oven drying of saturated soil according to Razkeh and Timourlou (2015) in which soil water percent calculated by following formula:

\section{$\theta=W w-W b / W b$}

Where $W w$ and $W_{b}$ are wet and dry sample weight, respectively. For stress treatments combined of plant wilting and soil water percentage of Fc were used according to table 4 . So that, control plots watered before appearance of wilting symptoms and reducing soil water to less than $85 \%$ of field capacity. Mild stress plots irrigated before slight wilt symptoms and depletion of soil water to $45 \%$ of Fc; sever stress plots irrigated before severe wilt symptoms and depletion of soil water to $25 \%$ of Fc.

Table 1, water stress determinants of experiment

\begin{tabular}{|llll|}
\hline Stress level & Symptoms on plant & Soil moisture relative to Field capacity (\%) & Soil moisture percentage) $\boldsymbol{\theta}$ (at irrigation time \\
\hline Control & Completely turgid leaves & 84.8 & 22.2 \\
\hline Mild & Mild wilt & 24.7 & 16.5 \\
\hline Sever & Wilt of upper and mild wilt of lower leaves & 23.56 & 11.85 \\
\hline
\end{tabular}

After monitoring and data collection along the growing seasons, at the end of two seasons yield and yield components measurements, vegetative attributes including plant height, mean number and length of monopodial and sympodial branches of 10 plant per plot recorded. Mean boll number and weight, seedcotton weight, fiber percentages calculated and recorded. Finally, the data analysed by $S A S^{\circledR} 9.2$. Mean compared statistically by Duncan test in probability level of $p<0.05$.

Table 2, Analysis of variance of vegetative traits 


\begin{tabular}{|c|c|c|c|c|c|c|c|c|c|c|c|}
\hline sov & $\begin{array}{l}\text { Degree } \\
\text { of } \\
\text { freedom }\end{array}$ & $\begin{array}{l}\text { Plant } \\
\text { height } \\
\text { (cm) }\end{array}$ & $\begin{array}{l}\text { Node } \\
\text { Number }\end{array}$ & $\begin{array}{l}\text { Height } \\
\text { to Node } \\
\text { ratio }\end{array}$ & $\begin{array}{l}\text { Monopodial } \\
\text { Number }\end{array}$ & $\begin{array}{l}\text { Monopodial } \\
\text { Length }\end{array}$ & $\begin{array}{l}\text { Sympodial } \\
\text { Number }\end{array}$ & $\begin{array}{l}\text { Sympodial } \\
\text { Length } \\
\text { (cm) }\end{array}$ & $\begin{array}{l}\text { Boll } \\
\text { per } \\
\text { plant }\end{array}$ & $\begin{array}{l}\text { Boll } \\
\text { weight } \\
\text { (gr) }\end{array}$ & $\begin{array}{l}\text { Yield } \\
\left(\mathrm{kg} \cdot \mathrm{ha}^{-1}\right)\end{array}$ \\
\hline $\operatorname{YEAR}(Y)$ & 1 & $3015^{\star \star}$ & $\begin{array}{l}50.07 \\
* *\end{array}$ & 17.59 ** & 11.57 ** & 787.4 ** & 198.37 ** & 181.86 ** & $3015^{\star \star}$ & $\underset{* *}{50.07}$ & 17.59 ** \\
\hline BLOCK (YEAR) & 2 & $\begin{array}{l}99.3 \\
\text { ns }\end{array}$ & $4.02 \mathrm{~ns}$ & $0.506 \mathrm{~ns}$ & $0.32 \mathrm{~ns}$ & $33.27 \mathrm{~ns}$ & $3.8 \mathrm{~ns}$ & 1.44 ns & $\begin{array}{l}99.3 \\
\text { ns }\end{array}$ & $\begin{array}{l}4.02 \\
\mathrm{~ns}\end{array}$ & $\begin{array}{l}0.506 \\
\mathrm{~ns}\end{array}$ \\
\hline STRESS (S) & 2 & $\begin{array}{l}4337.5 \\
* \star\end{array}$ & 67.55 & 4.11 ** & 3.92 ** & 8.1 * & 212.94 ** & 100.93 ** & $\begin{array}{l}4337.5 \\
\star \star\end{array}$ & $\begin{array}{l}67.55 \\
\star *\end{array}$ & $4.11 * *$ \\
\hline$S \times Y$ & 2 & $\begin{array}{l}93.9 \\
\text { ns }\end{array}$ & $5.63 \mathrm{~ns}$ & 0.94 ns & $0.22 \mathrm{~ns}$ & 84.5 * & 37.1 ** & $11.03 \mathrm{~ns}$ & $\begin{array}{l}93.9 \\
\text { ns }\end{array}$ & $\begin{array}{l}5.63 \\
\mathrm{~ns}\end{array}$ & $0.94 * *$ \\
\hline Ea & 8 & 62.67 & 2.84 & 0.17 & 0.33 & 14.8 & 3.02 & 4.01 & 62.67 & 2.84 & 0.17 \\
\hline CULTIVAR (CV) & 2 & 234.9 & 18.5 * & 2.1 * & 12.86 ** & 4763.8 ** & 34.23 ** & 1842.8 ** & $\underset{*}{234.9}$ & 18.5 * & 2.1 * \\
\hline$C V \times Y$ & 2 & 601.43 & $1.68 \mathrm{~ns}$ & $0.25 \mathrm{~ns}$ & 1.03 * & 544.75 ** & $2.54 \mathrm{~ns}$ & 179.22 ** & ${ }_{*}^{601.43}$ & $\begin{array}{l}1.68 \\
\mathrm{~ns}\end{array}$ & $0.25 \mathrm{~ns}$ \\
\hline$C V \times S$ & 4 & $\begin{array}{l}93.72 \\
\star\end{array}$ & $\begin{array}{l}11.72 \\
\mathrm{~ns}\end{array}$ & $0.16 \mathrm{~ns}$ & 2.97 ** & 74 ** & 83.7 ** & 122.36 ** & $\begin{array}{l}93.72 \\
\star\end{array}$ & $\begin{array}{l}11.72 \\
\mathrm{~ns}\end{array}$ & $0.16 \mathrm{~ns}$ \\
\hline$C V \times S \times Y$ & 4 & 163.5 & $7.24 \mathrm{~ns}$ & $0.31 \mathrm{~ns}$ & 1.14 * & 204.5 ** & $55.63 * *$ & 105.2 ** & ${ }_{*}^{163.5}$ & $\begin{array}{l}7.24 \\
\mathrm{~ns}\end{array}$ & $0.31 \mathrm{~ns}$ \\
\hline Eb & 2 & 30.44 & 4.39 & 0.193 & 0.185 & 10.63 & 1.2 & 5.73 & 30.44 & 4.39 & 0.193 \\
\hline C.V. (\%) & & 6.35 & 9.87 & 10.64 & 11.17 & 16.13 & 8.18 & 14.7 & 6.35 & 9.87 & 10.64 \\
\hline
\end{tabular}

$\mathrm{ns},{ }^{*}$ and $* *$ : Not significant, significant at $5 \%$ and $1 \%$ levels of probability, respectively.

Table 3, mean comparisons of cultivar properties in different levels of water stress

\begin{tabular}{|c|c|c|c|c|c|c|c|c|c|}
\hline $\begin{array}{l}\text { Stress } \\
\text { level }\end{array}$ & Variety & $\begin{array}{l}\text { Plant } \\
\text { height } \\
\text { (cm) }\end{array}$ & $\begin{array}{l}\text { Number of } \\
\text { monopodial branches } \\
\text { (cm) }\end{array}$ & $\begin{array}{l}\text { Length of } \\
\text { monopodial branches } \\
\text { (cm) }\end{array}$ & $\begin{array}{l}\text { Number of } \\
\text { sympodial branches }\end{array}$ & $\begin{array}{l}\text { Length of } \\
\text { sympodial branches } \\
\text { (cm) }\end{array}$ & $\begin{array}{l}\text { Boll } \\
\text { weight } \\
\text { (gr) }\end{array}$ & $\begin{array}{l}\text { Boll } \\
\text { per } \\
\text { plant }\end{array}$ & $\begin{array}{l}\text { Yield } \\
\text { (kg.ha' }\end{array}$ \\
\hline \multirow{3}{*}{$\begin{array}{l}\text { Control } \\
(85 \% \\
\text { Fc) }\end{array}$} & Khorshid & 97.7 a & $3.4 \mathrm{bc}$ & $3.96 \mathrm{de}$ & 14.3 bc & $5.5 \mathrm{c}$ & $4.4 \mathrm{ab}$ & $\begin{array}{l}28.2 \\
a\end{array}$ & $5575 a$ \\
\hline & Khordad & $\begin{array}{l}103.2 \\
a\end{array}$ & $4.1 \mathrm{ab}$ & $25.2 a b$ & $17 a b$ & $27.5 \mathrm{a}$ & $4.3 \mathrm{~b}$ & $\begin{array}{l}19.5 \\
b\end{array}$ & $\begin{array}{l}3760.5 \\
b c\end{array}$ \\
\hline & Varamin & $\begin{array}{l}104.5 \\
a\end{array}$ & $5.5 \mathrm{a}$ & $33.8 \mathrm{ab}$ & $22.5 \mathrm{a}$ & $24 a b$ & $4.8 \mathrm{a}$ & $\begin{array}{l}20.3 \\
b\end{array}$ & $4443 b$ \\
\hline \multirow{3}{*}{$\begin{array}{l}\text { Mild } \\
\text { stress } \\
\text { (45\% } \\
\text { Fc) }\end{array}$} & Khorshid & $84.2 \mathrm{~b}$ & $3.2 \mathrm{bc}$ & $3.5 \mathrm{de}$ & $11.8 \mathrm{bc}$ & $4.7 c$ & $3.97 \mathrm{~b}$ & $\begin{array}{l}17.2 \\
\mathrm{bc}\end{array}$ & $3060 \mathrm{c}$ \\
\hline & Khordad & $\begin{array}{l}83.25 \\
a b\end{array}$ & $4.6 \mathrm{ab}$ & $17.2 \mathrm{~cd}$ & $13.3 \mathrm{bc}$ & $24.5 a b$ & $4.25 \mathrm{~b}$ & $\begin{array}{l}12.8 \\
\mathrm{~cd}\end{array}$ & $2477 d$ \\
\hline & Varamin & $95.8 \mathrm{a}$ & $4.4 a b$ & $39.3 \mathrm{a}$ & $12.3 \mathrm{bc}$ & $24.5 a b$ & $4.4 a b$ & $\begin{array}{l}18.2 \\
b\end{array}$ & $3617 b$ \\
\hline \multirow{3}{*}{$\begin{array}{l}\text { Sever } \\
\text { stress } \\
(25 \% \\
\text { Fc) }\end{array}$} & Khorshid & $67.8 \mathrm{~b}$ & $3.08 \mathrm{c}$ & $2.7 \mathrm{e}$ & $9.8 \mathrm{c}$ & $3.6 \mathrm{c}$ & $3.5 c$ & $\begin{array}{l}12.5 \\
d\end{array}$ & 1996 e \\
\hline & Khordad & $73.5 \mathrm{~b}$ & $3.8 \mathrm{~b}$ & $22 \mathrm{bc}$ & $10.3 \mathrm{c}$ & $16.25 b$ & $3.65 c$ & $\begin{array}{l}11.7 \\
\mathrm{~d}\end{array}$ & 1908 e \\
\hline & Varamin & $71 \mathrm{~b}$ & $3.5 a b$ & $34.3 a b$ & $9.4 \mathrm{c}$ & $16 b$ & $3.8 \mathrm{c}$ & $\begin{array}{l}11.3 \\
d\end{array}$ & 1955 e \\
\hline
\end{tabular}

Means, in each column and for each factor, followed by at least one letter in common are not significantly different at the $5 \%$ of probability level, using Duncan's multiple range test.

Table 4. Pearson coefficient correlation of studied traits in experiment conditions 


\begin{tabular}{|c|c|c|c|c|c|c|c|c|c|c|}
\hline & $\begin{array}{l}\text { Plant } \\
\text { height }\end{array}$ & $\begin{array}{l}\text { Node } \\
\text { number }\end{array}$ & $\begin{array}{l}\text { Height to } \\
\text { node ratio }\end{array}$ & $\begin{array}{l}\text { Monopodial } \\
\text { branch number }\end{array}$ & $\begin{array}{l}\text { Monopodial } \\
\text { branch length }\end{array}$ & $\begin{array}{l}\text { sympodial } \\
\text { branch number }\end{array}$ & $\begin{array}{l}\text { sympodial } \\
\text { branch length }\end{array}$ & $\begin{array}{l}\text { Boll } \\
\text { per } \\
\text { plant }\end{array}$ & $\begin{array}{l}\text { Boll } \\
\text { weight }\end{array}$ & yield \\
\hline Plant height & 1 & & & & & & & & & \\
\hline Node number & $0.34^{\star}$ & 1 & & & & & & & & \\
\hline $\begin{array}{l}\text { Height to } \\
\text { node ratio }\end{array}$ & $0.74^{\star \star}$ & $-0.35^{\star}$ & 1 & & & & & & & \\
\hline $\begin{array}{l}\text { Monopodial } \\
\text { branch } \\
\text { number }\end{array}$ & $0.1 \mathrm{~ns}$ & $0.0015 \mathrm{~ns}$ & $0.08 \mathrm{~ns}$ & 1 & & & & & & \\
\hline $\begin{array}{l}\text { Monopodial } \\
\text { branch } \\
\text { length }\end{array}$ & $0.41 *$ & $-0.19 n s$ & $0.50 * \star$ & $0.33^{\star}$ & 1 & & & & & \\
\hline $\begin{array}{l}\text { sympodial } \\
\text { branch } \\
\text { number }\end{array}$ & $0.17 \mathrm{~ns}$ & $0.26 \mathrm{~ns}$ & $-0.02 \mathrm{~ns}$ & $0.56^{\star \star}$ & -0.09 ns & 1 & & & & \\
\hline $\begin{array}{l}\text { sympodial } \\
\text { branch } \\
\text { length }\end{array}$ & $0.28^{*}$ & 0.04 ns & $0.21 \mathrm{~ns}$ & $0.43^{*}$ & 0.70 ** & $0.2 \mathrm{~ns}$ & 1 & & & \\
\hline Boll per plant & $0.66^{\star \star}$ & $0.60 * *$ & $0.24 \mathrm{~ns}$ & $-0.05 \mathrm{~ns}$ & -0.07 ns & 0.24 ns & -0.086 ns & 1 & & \\
\hline Boll weight & $0.64^{\star \star}$ & $0.22 \mathrm{~ns}$ & $0.47 * \star$ & $0.45^{\star}$ & 0.33 ns & $0.41^{\star *}$ & -0.41 * & $0.42^{*}$ & 1 & \\
\hline yield & $0.73^{\star \star}$ & $0.57 * \star$ & $0.34^{*}$ & 0.10 ns & $0.06 \mathrm{~ns}$ & 0.31 * & $-0.0075 \mathrm{~ns}$ & $0.95^{\star \star}$ & $0.64^{\star \star}$ & 1 \\
\hline
\end{tabular}

$\mathrm{ns},{ }^{*}$ and $* *$ : Not significant, significant at $5 \%$ and $1 \%$ levels of probability, respectively.

\section{Declarations}

Acknowledgements

The authors are grateful to the Tehran province Natural Resources Research Center staff for their time and support in the experiment.

Authors' contributions

Ali Aaderi Arefi carried out the study, analyzed the data, and wrote the main manuscript text. Ali Reza Tavakoli designed the study and helped fulfill the experiment. All authors reviewed and approved the final manuscript.

Funding: Not applicable.

Availability of data and materials: Not applicable.

Ethics approval and consent to participate: Not applicable.

Consent for publication: Not applicable.

Competing interests: The authors declare that they have no competing interests.

\section{References}

1. Abdolrahmani Razkeh, N., Farrokhi Timourlou, R. Determining soil indices and water balance for scheduling an irrigation control center. Iranian Journal of Biosystems Engineering, 2015; 46(4): 425-433. doi: 10.22059/ijbse.2015.57349

2. Alishah O, MahmoodJanloo H, Hekmat MH, Naderi Arefi A, Sidmasoomi SY, Talat F. Investigation of genotypex environment interaction and yield stability of hopeful cotton (G. hirsutum L.) genotypes. Journal of Crop Breeding. 2019 Dec 10;11(31):226-36.

3. Alamdarloo EH, Khosravi H, Nasabpour S, Gholami A. Assessment of drought hazard, vulnerability and risk in Iran using GIS techniques. Journal of Arid Land. 2020 Nov;12(6):984-1000.

4. Arabsalmani M. and Baniani A. standards of potential assessment and damage evaluation of management and natural factors in different growth stage in cotton fields. 1th ed. Karaj: Agricultural Education and Extension publication; 2013.

5. Alishah 0., Ahmadilhah A. The effects of drought stress on improved cotton varieties in Golestan province of Iran. Journal of Plant production. 2009 [cited 2021September13];3(1):17-26. Available from: https://www.sid.ir/en/journal/ViewPaper.aspx?id=173920

6. Chandrasekar K, Sai MS. Monitoring of late-season agricultural drought in cotton-growing districts of Andhra Pradesh state, India, using vegetation, water and soil moisture indices. Natural Hazards. 2015 Jan 1;75(2):1023-46.

7. Bozorov TA, Usmanov RM, Yang H, Hamdullaev SA, Musayev S, Shavkiev J, Nabiev S, Zhang D, Abdullaev AA. Effect of water deficiency on relationships between metabolism, physiology, biomass, and yield of upland cotton (Gossypium hirsutum L.). Journal of Arid Land. 2018 Jun;10(3):441-56. 
8. Chen M, Liang F, Yan Y, Wang Y, Zhang Y, Tian J, Jiang C, Zhang W. Boll-leaf system gas exchange and its application in the analysis of cotton photosynthetic function. Photosynthesis Research. 2021 Jun 24:1-2.

9. DeLaune PB, Mubvumba P, Ale S, Kimura E. Impact of no-till, cover crop, and irrigation on Cotton yield. Agricultural Water Management. 2020 Apr 1;232:106038.

10. Etrat N, Abdul Q. Genetics of physiological, fiber and yield contributing traits in cotton grown under normal and water stress conditions. International Journal of Agriculture and Biology. 2020;23(6):1158-64.

11. Hu W, Snider JL, Wang H, Zhou Z, Chastain DR, Whitaker J, Perry CD, Bourland FM. Water-induced variation in yield and quality can be explained by altered yield component contributions in field-grown cotton. Field Crops Research. 2018 Jul 1;224:139-47.

12. Iqbal M, Ul-Allah S, Naeem M, ljaz M, Sattar A, Sher A. Response of cotton genotypes to water and heat stress: from field to genes. Euphytica. 2017 Jun;213(6):1-1.

13. Iqbal M, Iqbal MM, Ahmad S, Mahmood A, Akram M, Husnain H, Shahid M, Ahmad S, Raza A, Hussain A, Abid AD. Performance of early and late planting cotton genotypes under agro-ecological conditions of Multan, Punjab, Pakistan. Pakistan Journal of Agricultural Research. 2021;34(3):569-79.

14. Karademir C, Karademir E, Ekinci R, Berekatoğlu K. Yield and fiber quality properties of cotton (Gossypium hirsutum L.) under water stress and non-stress conditions. African Journal of Biotechnology. 2011;10(59):12575-83.

15. Khan A, Pan X, Najeeb U, Tan DK, Fahad S, Zahoor R, Luo H. Coping with drought: stress and adaptive mechanisms, and management through cultural and molecular alternatives in cotton as vital constituents for plant stress resilience and fitness. Biological research. $2018 ; 51$.

16. Khan N, Han Y, Wang Z, Wang G, Feng L, Yang B, Li Y. Role of proper management of nitrogen in cotton growth and development. International Journal of Biosciences. 2019;14(5):5.

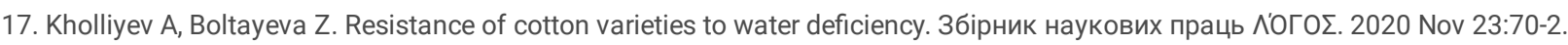

18. Balkcom KS, Bergtold JS, Monks CD, Price AJ, Delaney DP. Planting and defoliation timing impacts on cotton yield and quality. InBeltwide Cotton Conferences, New Orleans, Louisiana, January 2010 Jan 15 (pp. 4-7).

19. Liu J, Ma Y, Lv F, Chen J, Zhou Z, Wang Y, Abudurezike A, Oosterhuis DM. Changes of sucrose metabolism in leaf subtending to cotton boll under cool temperature due to late planting. Field Crops Research. 2013 Mar 20;144:200-11.

20. Naderi Arefi A, Ahmadi A, Sabokdast M. Effect of water deficit stress on leaf physiological traits and drought tolerance of cotton genotypes. Journal of Crops Improvement. 2017 Feb 19;18(4):987-99.

21. Osterhuis DM. Stress Physiology in Cotton (Translate by Ali Naderi Arefi). 1th ed,Gorgan: Nouruzi; 2016.

22. Papastylianou PT, Argyrokastritis IG. Effect of limited drip irrigation regime on yield, yield components, and fiber quality of cotton under Mediterranean conditions. Agricultural Water Management. 2014 Aug 1;142:127-34.

23. Pilon C, Loka D, Snider JL, Oosterhuis DM. Drought-induced osmotic adjustment and changes in carbohydrate distribution in leaves and flowers of cotton (Gossypium hirsutum L.). Journal of Agronomy and Crop Science. 2019 Apr;205(2):168-78.

24. Sahito A, Baloch ZA, Mahar A, Otho SA, Kalhoro SA, Ali A, Kalhoro FA, Soomro RN, Ali F. Effect of water stress on the growth and yield of cotton crop (Gossypium hirsutum L.). American Journal of Plant Sciences. 2015 Apr 10;6(07):1027.

25. Saleem MF, Sammar Raza MA, Ahmad S, Khan IH, Shahid AM. Understanding and mitigating the impacts of drought stress in cotton-a review. Pakistan Journal of Agricultural Sciences. 2016 Sep 1;53(3).

26. Sawan ZM. Climatic variables: Evaporation, sunshine, relative humidity, soil and air temperature and its adverse effects on cotton production. Information processing in agriculture. 2018 Mar 1;5(1):134-48.

27. Sharafati A, Nabaei S, Shahid S. Spatial assessment of meteorological drought features over different climate regions in Iran. International Journal of Climatology. 2020 Mar 15;40(3):1864-84.

28. Schober P, Boer C, Schwarte LA. Correlation coefficients: appropriate use and interpretation. Anesthesia \& Analgesia. 2018 May 1;126(5):1763-8.

29. Sezener V, Basal H, Peynircioglu C, Gurbuz T, Kizilkaya K. Screening of cotton cultivars for drought tolerance under field condition. Turkish Journal Of Field Crops. 2015 Jan 1;20(2):223-32.

30. Smith DL, Hamel C, editors. Crop yield: physiology and processes. Springer Science \& Business Media; 2012 Dec 6.

31. Stewart JM, Oosterhuis D, Heitholt JJ, Mauney JR, editors. Physiology of cotton. Springer Science \& Business Media; 2009 Nov 4.

32. Ul-Allah S, Rehman A, Hussain M, Farooq M. Fiber yield and quality in cotton under drought: Effects and management. Agricultural Water Management. 2021 Sep 1;255:106994.

33. Wu H, Wang X, Xu M, Zhang J. The effect of water deficit and waterlogging on the yield components of cotton. Crop Science. 2018 Jul;58(4):1751-61.

34. Zhang H, Khan A, Tan DK, Luo H. Rational water and nitrogen management improves root growth, increases yield and maintains water use efficiency of cotton under mulch drip irrigation. Frontiers in Plant Science. 2017 May 30;8:912.

35. Zhang H, Li D, Zhou Z, Zahoor R, Chen B, Meng Y. Soil water and salt affect cotton (Gossypium hirsutum L.) photosynthesis, yield and fiber quality in coastal saline soil. Agricultural Water Management. 2017 Jun 1;187:112-21.

36. Zhao W, Wang R, Hu W, Zhou Z. Spatial difference of drought effect on photosynthesis of leaf subtending to cotton boll and its relationship with boll biomass. Journal of Agronomy and Crop Science. 2019 Jun; 205(3):263-73. 